\title{
The Role of DNA Gyrase (gyrA) in Ciprofloxacin- Resistant Locally Isolates Pseudomonas aeruginosa in Al-Khadhmiya Teaching Hospital Baghdad, Iraq
}

\author{
Jabbar S. Hassan ${ }^{1}$, Montaha A. Al-Safar ${ }^{2}$ and Thanaa Rasheed Abdul Rhman ${ }^{1}$ \\ ${ }^{1}$ Department of Microbiology, College of Medicine, Al-Nahrain University, Iraq. ${ }^{2}$ Community Health, Medical \\ Technical Institute, Middle Technical University Baghdad, Iraq.
}

\begin{abstract}
Ciprofloxacin comprise a medically effective and generally utilized class of broad-spectrum antibiotics; as a result of the intensive use of this type of therapy, bacteria have become resistant, lead to minimize the usage of such bactericides in field of management as well as treatment of microbial illness. Pseudomonas aeruginosa one of important pathogens that case wide spectrum of infections, the evolution of ciprofloxacin-resistant Pseudomonas aeruginosa were notify. In this investigation $\mathbf{5 0}$ clinical isolates of Pseudomonas aeruginosa were collected, antibiotic susceptibility test for ciprofloxacin by using the Kirby-Bauer technique as well as MIC was performed to all these isolates. Specific primers sequences for detection of Topoisomerase II (gyrA) genes were used by conventional PCR then, PCR product were treated with Sac II enzyme at $37^{\circ} \mathrm{C}$ for $\mathbf{2} \mathrm{h}$, then restriction bands were recovered by gel electrophoresis. From Fifty Pseudomonas aeruginosa isolates enrolled in this study, 33(66\%) show sensitive to Ciprofloxacin, 17(34\%) reported resistant to Ciprofloxacin. RFLP-PCR showed that out of 17 isolates resistant to Ciprofloxacin mutation inDNA gyrase (GyrA) were detected in six (35.2 \%) isolated while the reminder $11(64.7 \%)$ has no mutation. The presence of mutations in Topoisomerases II genes mediate Ciprofloxacin defeat as therapy for Pseudomonas aeruginosa. The current venture, were made to demonstrate Topoisomerase II genes (GyrA mutations in Pseudomonas aeruginosa that could be responsible for molecular mechanism of Ciprofloxacin resistance.
\end{abstract}

Keywords: Topoisomerase II genes, DNA gyrase, Ciprofloxacin, RFLP-PCR, Sacll enzyme.

\footnotetext{
*Correspondence: dr.montahabio@yahoo.com

(Received: 01 January 2019; accepted: 24 February 2019)

Citation: Jabbar S. Hassan, Montaha A. Al-Safar and Thanaa Rasheed Abdul Rhman, The Role of DNA Gyrase (gyrA) in CiprofloxacinResistant Locally Isolates Pseudomonas aeruginosa in Al-Khadhmiya Teaching Hospital Baghdad, Iraq, J Pure Appl Microbiol., 2019; 13(1):499-503 doi: 10.22207/JPAM.13.1.56

(C) The Author(s) 2019. Open Access. This article is distributed under the terms of the Creative Commons Attribution 4.0 International License which permits unrestricted use, sharing, distribution, and reproduction in any medium, provided you give appropriate credit to the original author(s) and the source, provide a link to the Creative Commons license, and indicate if changes were made.
} 


\section{INTRODUCTION}

Pseudomonas aeruginosa causes hospital acquired infection due to its ubiquitous nature, capability to continue to exist in damp environments, what's more, un-respond to numerous anti-infection agents. Quinolones are one of these drug group in which Pseudomonas aeruginosa resistant is being reported and has been identified as a motive of remedy failure ${ }^{1}$. On this group, Ciprofloxacin is the maximum antibiotic trends towards Gram-negative bacteria, for examples Salmonella species, Acinetobacter baumannii and Pseudomonas aeruginosa, Ciprofloxacin is a 2 nd-genration agent, belong to the quinolones derivates. Which have ability to interfered with the bacterial DNA gyrase, it has bactericidal activity with a wide spectrum in opposition to Gram positive and Gram-negative microorganism².

As a result, to critical use of Ciprofloxacin as one of the mighty agents in organization fluoroquinolones against $P$. aeruginosa has prompted the set off the improvement of resistant strains $^{3}$. Quinolones has the ability to sort kind two topoisomerases, which can be crucial compounds in arrange the topological condition of DNA via its replication and transcription. DNA gyrase is made from two $A$ and $B$ fragments, these fragments encoded through the gyrA and gyrB genes ${ }^{4}$.

Topoisomerases are assuming crucial elements of DNA metabolism ${ }^{5}$. Quinolones conflict with the motion of DNA gyrase, a critical bacterial kind II DNA topoisomerase ${ }^{6}$.

Several researches have been exhibited that mutations imparting fluoroquinolone resistance in $P$. aeruginosa may attributed to amendment in DNA gyrase, hypothesizing that faded sensitivity to fluoroquinolone result from inhibition of DNA supercoiling in resistant isolates of Gram-negative pathogens and alteration in gyrA consider leading causes in this resistance ${ }^{7}$. This study aims to demonstrate Topoisomerase II genes (GyrA mutations in Pseudomonas aeruginosa that could be responsible for molecular mechanism of Ciprofloxacin resistance.

\section{MATERIALS AND METHODS}

From April 2015 to March 2016, fifty clinical isolates of $P$. aeruginosa were collected from different infectious source in patients who admitted into Al-Khadhmiya Teaching Hospital by using cotton swabs, samples were culture immediately on Nutrient, Blood and Mac-Conkey agar at $37^{\circ} \mathrm{C}$ for 24 hours, the isolated colony were identified by biochemical test and Epi 20-E system.

All isolates enrolled in this study were tested by disk diffusion methods to determine antimicrobial susceptibility to Ciprofloxacin $(5 \mu \mathrm{g})$, when the inhibition zone across the disks was formed it measured and comparison with the break points of clinical laboratory institute $(\mathrm{CLSI})^{8}$.

The MIC became completed by way of a standard agar dilution approach and has been carried out for determination the lowest antibiotics concentration that prevents the growth of bacteria, the break points encouraged by using CLSI have been used for ciprofloxacin (susceptible $\leq 1 \mu \mathrm{g} / \mathrm{mL}$; resistant $\geq$ four $\mu \mathrm{g}$ / $\mathrm{mL}$ ). E. coli ATCC25922 isolates from central public health laboratory standard strain used as negative control. This study authorized by Institutional Review Board (IRB) in the College of Medicine /AL-Nahrain University, and conducted in the Microbiology Department on the College of Medicine Al-Nahrain University.

\section{DNA Extractions}

DNA extraction was done by a simple and rapid procedure boiling according to Reischl et al. ${ }^{9}$. Briefly one $\mathrm{ml}$ of an overnight bacterial growth became centrifuged, at $14000 \mathrm{rpm}$ for two minutes, the supernatant was eliminated and pellet became suspended in 2 hundred $\mathrm{ml}$ lysis buffer containing $1 \%$ Triton $\mathrm{X}-100,0.5 \%$ Tween 20, $10 \mathrm{mM}$ Tris- $\mathrm{HCl}(\mathrm{pH} \mathrm{8.0)}$, and $1 \mathrm{mM}$ EDTA and incubated in a screw-cap reaction tube for $10 \mathrm{~min}$ in a boiling water bath, the suspension turned into centrifuged at $14000 \mathrm{rpm}$ for two minutes, supernatant containing DNA turned into Eppendorf tube and used as a template for PCR assay targeting the Gyrase A genes.

\section{PCR Amplification}

Specific primers sequences targeting DNA gyrase according to Kureishi et al. ${ }^{10}$ were used for PCR amplification and examined the connection among gene mutations of topoisomerase II (gyrA) with resistance to Ciprofloxacin in P.aeruginosa, this genemake in Alpha DNA ${ }^{\circledast}$ (Canada) table (1). 
Table 1. Sequences of primer that use to detection II topoisomerase (GyrA gene).

\begin{tabular}{|c|c|c|c|}
\hline & $\begin{array}{l}\text { Nucleotide } \\
\text { sequences }\end{array}$ & Reference & Products \\
\hline Genes & 3') & & $b P$ \\
\hline $\mathrm{F}$ & $\begin{array}{l}\text { GACGGCCTGA- } \\
\text { AGCCGGTGCAC }\end{array}$ & & 416 \\
\hline Gyrase A R & $\begin{array}{l}\text { GCCCACGGCGA- } \\
\text { TACCGCTGGA. }\end{array}$ & (10) & \\
\hline
\end{tabular}

The primers have been diluted via adding nuclease free water consistent with the manufacturer commands. The master mix contents have been thawed at room temperature before use, all precautions have been taken to avoid any contamination. $2 \mu \mathrm{l}$ from forward and reverse primer for Gyrase A gene had been added in single pre-mixed PCR reaction tube, then DNA template equal to Five microliter had been added. Twelve and a 1/2 microliters of GoTaq ${ }^{\circledR}$ Green Master Mix was added for each reaction tube, the quantity changed into completed to $25 \mu \mathrm{l}$ with Deionized Nuclease -Free and tubes had been spun down to ensure mixing of the reaction components.

Non- DNA template in PCR mixture were used as negative control. The tubes have been positioned at PCR machine (Eppendorf Master Cycler) and the PCR software, with the proper cycling situations pre-installed, Amplification reaction for Gyrase $A$ gene become as follows: $94^{\circ} \mathrm{C}$ for $3 \mathrm{~min}$ followed by 40 cycles of $94^{\circ} \mathrm{C}$ for $30 \mathrm{sec}, 50^{\circ} \mathrm{C}$ for $30 \mathrm{sec}$, and $72^{\circ} \mathrm{C}$ for $60 \mathrm{sec}$, terminating in $72^{\circ} \mathrm{C}$ for $7 \mathrm{~min}, 10 \mu \mathrm{l}$ from PCR product was subjected to $1 \%$ (wt/vol) agarose gel electrophoresis with $0.5 \mu \mathrm{g} / \mathrm{ml}$ ethidium bromide, Five microliters of the 100bp DNA ladder marker turned into subjected to electrophoresis in a single lane. Amplicon visualization was done the use of a UV trans illuminator.

\section{REFLP- PCR assay}

In order to detect mutation in Gyrase A gene PCR -REFLP with Cfr42 I (Sacll) enzyme $(10 \mathrm{U} / \mu \mathrm{L})$ were used according to manufacture instruction (Thermo Fisher Scientific). Briefly, The PCR product were treated with Sac II enzyme at $37^{\circ} \mathrm{C}$ for $2 \mathrm{hr}$. Restriction enzyme is inactivated by incubation at $65^{\circ} \mathrm{C}$ for $20 \mathrm{~min}$. then restriction bands were recovered by gel electrophoresis.

\section{RESULTS}

Disc diffusion test showed that out of 50 Pseudomonas aeruginosa isolates enrolled in this study, 33(66\%) were delicate to ciprofloxacin, 17(34\%) were impervious to Ciprofloxacin.

Determination of MIC to Ciprofloxacin reveals that out of 17 bacteria resistant to Ciprofloxacin, 8 isolates had MIC $64 \mu \mathrm{g} / \mathrm{mL}$. Three isolates with MIC $32 \mu \mathrm{g} / \mathrm{mL}$. five isolates with MIC $16 \mu \mathrm{g} / \mathrm{mL}$ Conventional PCR affirmed existence of Gyrase $A$ genes in all resistant strain of $P$. aeruginosa for Ciprofloxacin fig. 1. RFLP-PCR methods showed that out of 17 isolates resistant to Ciprofloxacin mutation in type II topo-isomerase genes (GyrA) were found in 6 (35.2\%) isolated indicate by single band while the reminder 11 $(64.7 \%)$ has no mutation indicate by double fragment Fig. 2.

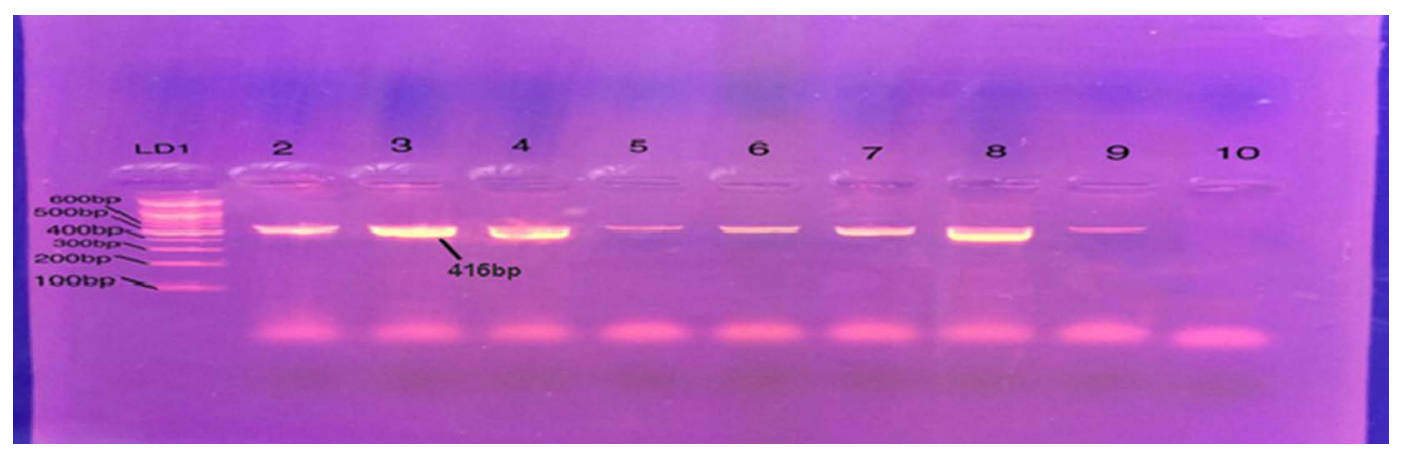

Fig. 1. PCR products amplified with gyrA specific primers in resistant samples before the restriction $416 \mathrm{bp}$. 


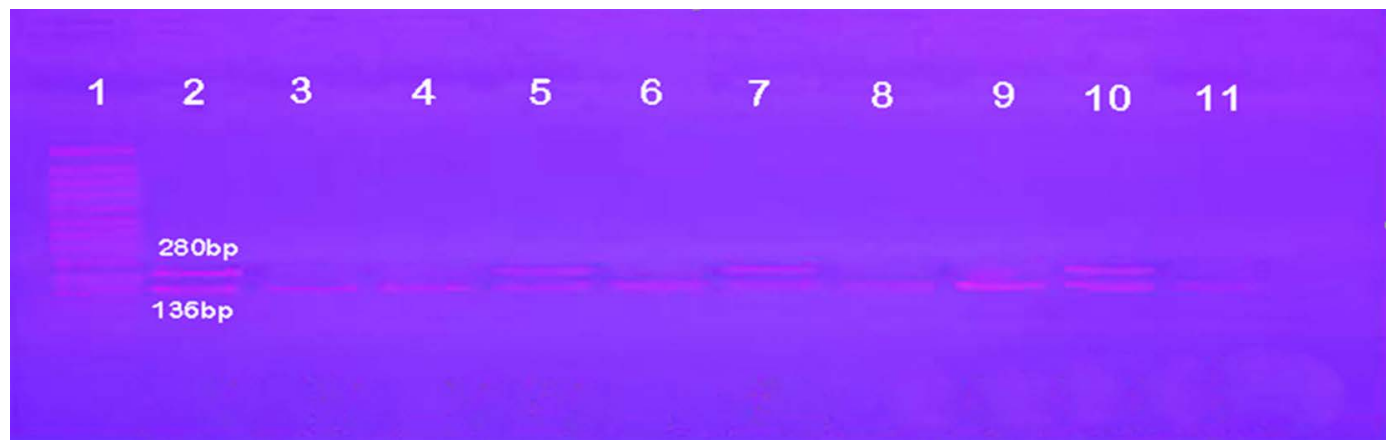

Fig. 2. RFLP-PCR assay using restriction enzymes Sac II were used to detect the mutations in the present samples. mutant strains, indicate by single band $(3,4,6,8,9,11)$, Non-Mutant strain indicate by double fragment.

\section{DISCUSSION}

Pseudomonas aeruginosa are recognized as most important Gram-negative pathogen, remains a challenge to many doctors and researchers because of their ability to resist many of the antibiotics using different mechanisms, and one of these mechanisms' mutation in DNA gyrase (type II Topoisomerase) which is essential enzyme contributory in chromosomal DNA replication and segregation.

In the present study, the percentage of Ciprofloxacin resistant (34\%) is lower than the percentage recorded in Iraqi by Zeyad K. et al 2018 who reported $83.50 \%$ out of 103 Pseudomonas aeruginosa isolates ${ }^{11}$.

Other study conducted in India by Goel et al (2011) stated that increasing fluoroquinolone Pseudomonas aeruginosa resistant ${ }^{12}$. This difference may be explained by small size of Pseudomonas aeruginosa isolated in current study in compare with other studies, further more some Iraqi hospitals initiate stewardship antibiotic program surveillance which limited used of fluoroquinolone.

According to AL-Muhannak (2012), appropriate antibiotic dose and convenient medical procedures supervision can limit and sometime prevent bacterial resistant to quinolone, in our study 33(66\%) were sensitive to Ciprofloxacin, which confirms AL-Muhannak (2012) observation ${ }^{13}$.

So, this result may be highlighting that bacteria responsible for hospital acquired infection such as Pseudomonas aeruginosa may develop resistant when steadily contact with a wide range of antibiotic, and as results to this events surveillance strategies in hospitalized patients may lead to minimized infections with resistant bacteria.

One of the major mechanisms used by bacteria to resist fluoroquinolone is mutation in topoisomerases genes, Noticeably in gyrA on codon 83 and $87^{14}$. This mutation lead to variation in amino acid which are found in regions that responsible for quinolone-resistance (QRDRs), since this area contains this type of topoisomerase $^{15}$.

Have crucial role in the replications and segregations of DNA, furthermore these enzymes considered as a main target for antibiotic ${ }^{16}$.

Our finding that the out of 17 isolates resistants to Ciprofloxacin, 11 (64.7\%) has no mutation, these results were consistent with Varug heseet al (2018) ${ }^{17}$.

This could be attributed to the presence of other mechanisms that make Pseudomonas aeruginosa resistant to fluoroquinolone antibiotic patterns such as mutation in other genes such as parE, parC gene efflux pump, changes in the target protein of antibiotic, furthermore minimize in the penetration ability of an antibiotic is also a resistance mechanism for many classes of antibiotics $^{18}$.

In conclusion, this study has uncovered that the changes in Topoisomerases II (gyrA) play crucial role in the mechanism of quinolone resistance among the locally separate $P$. aeruginosa in Al-Khadhmiya Teaching Hospital Baghdad Iraqi. 


\section{ACKNOWLEDGEMENT}

None.

\section{CONFLICT OF INTEREST}

The author declares that there are no conflict of interest.

\section{REFERENCES}

1. Cometta A., Baumgartner J. D., Lew D., Zimmerli W., Pittet D., Chopart P., Schaad U., Herter C., Eggimann P., Huber O., et al. Prospective randomized comparison of imipenem mono-therapy with imipenem plus netilmicin for treatment of severe infections in nonneutropenic patients. Antimicrob. Agents Chemother, 1994; 38: 1309-1313.)

2. Takenouchi T, Sakagawa E, Sugawara M: Detection of gyrA mutations among 335 Pseudomonas aeruginosa strains isolated in Japan and their susceptibilities to fluoroquinolones. Anti-microbial agents and chemotherapy, 1999, 43(2): 406-409.

3. Gorgani N, Ahlbrand S, Patterson A, Pourmand N: Detection of point mutations associated with antibiotic resistance in Pseudomonas aerug-inosa. International journal of antimicrobial agents 2009; 34(5): 414-418.)

4. Akasaka T, Tanaka M, Yamaguchi A, Sato K: Type II topoisomerase mutations in fluoroquinolone-resistant clinical strains of Pseudomonas aeruginosa isolated in 1998 and 1999: role of target enzyme in mechanism of fluoroquinolone resistance. Antimicrobial agents and chemo-therapy, 2001; 45(8): 2263-2268.

5. Dougherty TJ, Nayar A, Newman JV, Hopkins S, Stone $G G$, Johnstone $M$, Shapiro $A B$, Cronin $M$, Reck $F$, Ehmann DE: NBTI 5463 is a novel bacterial type II topoisomerase inhibitor with activity against gramnegative bacteria and in vivo efficacy. Antimicrobial agents and chemotherapy, 2014; 58(5): 2657-2664.)

6. Diver JM, Schollaardt T, Rabin HR, Thorson C, Bryan LE: Persistence mechanisms in Pseudomonas aeruginosa from cystic fibrosis patients undergoing ciprofloxacin therapy. Antimicrobial agents and chemotherapy, 1991; 35(8): 1538-1546

7. Zhanel GG, Karlowsky JA, Saunders MH, Davidson RJ, Hoban DJ, Hancock RE, McLean I, Nicolle LE: Development of multiple-antibiotic-resistant (Mar) mutants of Pseudomonas aeruginosa after serial exposure to fluoroquinolones. Antimicrobial agents and chemotherapy. 1995; 39(2):489-95.

8. Clinical and Laboratory Standards Institute (CLSI). Performance standards for antimicrobial susceptibility testing, CLSI Supplement M100S. 26th ed. Clinical and
Laboratory Standards Institute, Wayne, PA, USA, 2016. 9. Reischl U, Linde HJ, Metz M, Leppmeier B, Lehn N. Rapid identification of methicillin-resistant Staphylococcus aureus and simultaneous species confirmation using real-time fluore-scence PCR. Journal of Clinical Microbiology, 2000; 38(6): 2429-33.

10. Kureishi A, Diver JM, Beckthold B, Schollaardt T, Bryan LE. Cloning and nucleotide sequence of Pseudomonas aeruginosa DNA gyrase gyrA gene from strain PAO1 and quinolone-resistant clinical isolates. Antimicrobial agents and chemotherapy, 1994; 38(9): 1944-52

11. Hussein ZK, Kadhim HS, Hassan JS. 3. Detection of new delhi metallo-beta-lactamase-1 (blandm-1) in carbapenem resistant Pseudomonas aeruginosa isolated from clinical samples in Wasit hospitals. Iraqi Journal of Medical Sciences, 2018; 16(3): 239-46.

12. Goel N, Wattal C, Oberoi JK, Raveendran R, Datta S, Prasad KJ. Trend analysis of antimicrobial consumption and development of resistance in non-fermenters in a tertiary care hospital in Delhi, India. Journal of antimicrobial chemo-therapy, 2011; 66(7):1625-30.

13. AL-Muhannak FH, Al-Mohana A. Spread of Some Extended-spectrum Beta-lactamases: In Clinical Isolates of Gram-negative Bacilli in Najaf. LAP LAMBERT Academic Publishing; 2012.

14. Valdezate S, Vindel A, Echeita A, Baquero F, Canto $\mathrm{R}$ : Topoisomerase II and IV quinolone resistancedetermining regions in Stenotrophomonas maltophilia clinical isolates with different levels of quinolone susceptibility. Antimicrobial agents and chemotherapy, 2002; 46(3): 665-671.

15. (De la Fuente CM, Dauros SP, Bello TH, Dominguez YM, Mella MS, Sepulveda AM, Zemelman ZR, Gonzalez RG: [Mutations in gyrA and gyrB genes among strains of Gram-negative bacilli isolated from Chilean hospitals and their relation with resistance to fluoroquinolones]. Revista medica de Chile, 2007; 135(9): 1103-1110.

16. Wang YT, Lee MF, Peng CF. Mutations in the quinolone resistance-determining regions associated with ciprofloxacin resistance in Pseudomonas aeruginosa isolates from Southern Taiwan. Biomarkers and Genomic Medicine, 2014; 6(2): 79-83.

17. Varughese LR, Rajpoot M, Goyal S, Mehra R, Chhokar $\mathrm{V}$, Beniwal V. Analytical profiling of mutations in quinolone resistance determining region of gyrA gene among UPEC. PloS one, 2018; 13(1): e0190729

18. Farahi RM, Ali AA, Gharavi S. Characterization of gyrA and parC mutations in ciprofloxacin-resistant Pseudomonas aeruginosa isolates from Tehran hospitals in Iran. Iranian Journal of Microbiology, 2018; 10(4): 242. 